\begin{tabular}{r|l|l|l}
$\begin{array}{c}\text { Case Reports in } \\
\text { Gastroenterology }\end{array}$ & $\begin{array}{l}\text { Case Rep Gastroenterol 2010;4:369-373 } \\
\text { DOl: 10.1159/000320675 }\end{array}$ & $\begin{array}{l}\text { Published online: } \\
\text { September 18, 2010 }\end{array}$ & $\begin{array}{l}\text { O 2010 S. Karger AG, Basel } \\
\text { ISSN 1662-0631 } \\
\text { www.karger.com/crg }\end{array}$ \\
\hline
\end{tabular}

This is an Open Access article licensed under the terms of the Creative Commons AttributionNonCommercial-NoDerivs 3.0 License (www.karger.com/OA-license), applicable to the online version of the article only. Distribution for non-commercial purposes only.

\title{
Adenosquamous Carcinoma and Pure Squamous Cell Carcinoma of the Pancreas: Report of two Cases
}

\author{
Tadashi Terada \\ Department of Pathology, Shizuoka City Shimizu Hospital, Shizuoka, Japan
}

\section{Key Words}

Pancreas - Adenosquamous carcinoma - Squamous cell carcinoma - Histopathology

\begin{abstract}
Adenosquamous carcinoma (ASC) and pure squamous cell carcinoma (SCC) of the pancreas are very rare diseases. The author herein reports two cases of ASC and SCC of the pancreas. The first case is ASC. An 80-year-old woman was admitted to our hospital because of abdominal pain and weakness. Imaging modalities including CT, MRI and ERCP revealed a pancreatic body tumor. Distal partial resection of the pancreas and splenectomy were performed. Grossly, an infiltrative solid tumor measuring $3 \times 4 \times 4 \mathrm{~cm}$ was present in the pancreatic body. Histologically, it was an ASC consisting of poorly differentiated adenocarcinoma element (20\% in area) and SCC element $(80 \%)$. There was a gradual transition between the two. Many perineural invasions and lymphovascular permeations were recognized. The patient died of systemic metastasis five months after operation. The second case is an SCC. A 69-year-old woman presented with abdominal pain and jaundice. Imaging modalities including $C T, M R I$ and ERCP revealed a tumor in the head of the pancreas. Pancreaticoduodenectomy was performed. Grossly, an infiltrative solid tumor measuring $5 \times 5 \times 6 \mathrm{~cm}$ was present. Histologically, the tumor was pure SCC. The SCC was moderately differentiated SCC. A large number of perineural invasions and lymphovascular permeations were present. The patient died of systemic metastasis three months after operation. The author speculates that ASC of the pancreas may be derived from squamous tansdifferentiation of adenocarcinoma element or from pluripotent stem cells, and that SCC of the pancreas may arise from malignant transformation of squamous metaplasia of pancreatic ducts or from pluripotent stem cells.
\end{abstract}




\begin{tabular}{r|l|l|l}
$\begin{array}{c}\text { Case Reports in } \\
\text { Gastruanteriology }\end{array}$ & $\begin{array}{l}\text { Case Rep Gastroenterol 2010;4:369-373 } \\
\text { DOI: 10.1159/000320675 }\end{array}$ & $\begin{array}{l}\text { Published online: } \\
\text { September 18, 2010 }\end{array}$ & $\begin{array}{l}\text { O 2010 S. Karger AG, Basel } \\
\text { ISSN 1662-0631 } \\
\text { www.karger.com/crg }\end{array}$ \\
\hline
\end{tabular}

\section{Introduction}

Adenosquamous carcinoma (ASC) of the pancreas is very rare, its incidence being $3-4 \%$ of all pancreatic malignancies [1]. ASC of the pancreas has been sporadically reported as case reports, and there are several comprehensive reports of a relatively large series [2-5]. Squamous cell carcinoma (SCC) of the pancreas is a much rarer disease. A few case reports have been published [6-9], but there are no comprehensive studies of large series. The author reports herein one case of ASC and one case of pure SCC of the pancreas.

\section{Case 1}

An 80-year-old woman was admitted to our hospital because of abdominal pain and weakness. Imaging modalities including CT, MRI and ERCP revealed a pancreatic body tumor. Distal partial resection of the pancreas and splenectomy were performed. Grossly, an infiltrative solid tumor measuring $3 \times 4 \times 4 \mathrm{~cm}$ was recognized. Histologically, it was an ASC consisting of moderately to poorly differentiated adenocarcinoma element (20\% in area) (fig. 1a) and SCC element (80\%) (fig. 1b). There was a gradual transition between the two. There were also equivocal malignant cells as to SCC and adenocarcinoma. Areas of pleomorphism and tumor giant cells were present. The adenocarcinoma cells were positive with PAS and alcian blue staining, indicating positive mucins. Numerous perineural invasions and lymphovascular permeations were recognized. The tumor cells invaded the peripancreatic fat tissue. The patient died of systemic metastasis five months after operation.

\section{Case 2}

A 69-year-old woman was admitted to our hospital with abdominal pain and jaundice. Imaging modalities including CT, MRI and ERCP revealed a tumor in the head of the pancreas. Pancreaticoduodenal resection and cholecystectomy were performed. Grossly, an infiltrative solid tumor measuring $5 \times 5 \times 6 \mathrm{~cm}$ was recognized. Histologically, the tumor is pure SCC (fig. $2 \mathrm{a}$ ). The SCC was moderately differentiated SCC with keratinization (fig. 2b) and intercellular bridges (fig. 2c). Many perineural invasions and lymphovascular permeations were present. The tumor cells invaded the extrahepatic bile duct, duodenum and peripancreatic fat tissue and involved peripancreatic lymph nodes. The patient died of systemic metastasis three months after operation.

\section{Discussion}

According to the WHO classification [10], ASC is defined as a rare pancreatic neoplasm characterized by the presence of a variable proportion of mucin-producing glandular elements and squamous components. The squamous component should account for at least $30 \%$ of the tumor tissue. Our case 1 fulfills these criteria.

ASC of the pancreas is a rare tumor with an incidence of $3-4 \%$ of all pancreatic malignancies $[1,10]$. This neoplasm is an aggressive tumor with a poor prognosis. The mean prognosis period is about six months $[1,2,4]$; it is shorter than for ordinary ductal adenocarcinoma of the pancreas [10]. The most involved site is the pancreatic head, followed by the body and tail [4]. In the present case of ASC, the prognosis was five months, and the ASC was present in the body of the pancreas.

The pathogenesis of ASC is unclear. Two theories exist: (1) the squamous element is derived from squamous transdifferentiation of adenocarcinoma element; (2) the ASC of 


\begin{tabular}{r|l|l|l}
$\begin{array}{r}\text { Case Reports in } \\
\text { Gastroanterology }\end{array}$ & $\begin{array}{l}\text { Case Rep Gastroenterol 2010;4:369-373 } \\
\text { DOl: 10.1159/000320675 }\end{array}$ & $\begin{array}{l}\text { Published online: } \\
\text { September 18, 2010 }\end{array}$ & $\begin{array}{l}\text { I 2010 S. Karger AG, Basel } \\
\text { ISSN 1662-0631 } \\
\text { www.karger.com/crg }\end{array}$ \\
\hline
\end{tabular}

the pancreas arises from pluripotent stem cells. In our case, the adenocarcinoma and squamous elements were mixed up, and a gradual transition was recognized between the two.

SSC of the pancreas is much rarer than ASC. The exact incidence is unknown. There are a few case reports of SCC of the pancreas [6-9], but no comprehensive reports of large series. This entity is not listed in the WHO book [10].

An analysis of the four cases reported previously [6-9] shows that SCC is an aggressive tumor with a poor prognosis, like ASC of the pancreas. In the present SCC of the pancreas, the prognosis was only three months. The pathogenesis of SCC of the pancreas is unknown. The author speculates that SCC of the pancreas may be derived from malignant transformation of squamous metaplasia of pancreatic ducts, or may arise from pluripotent stem cells in the pancreas.

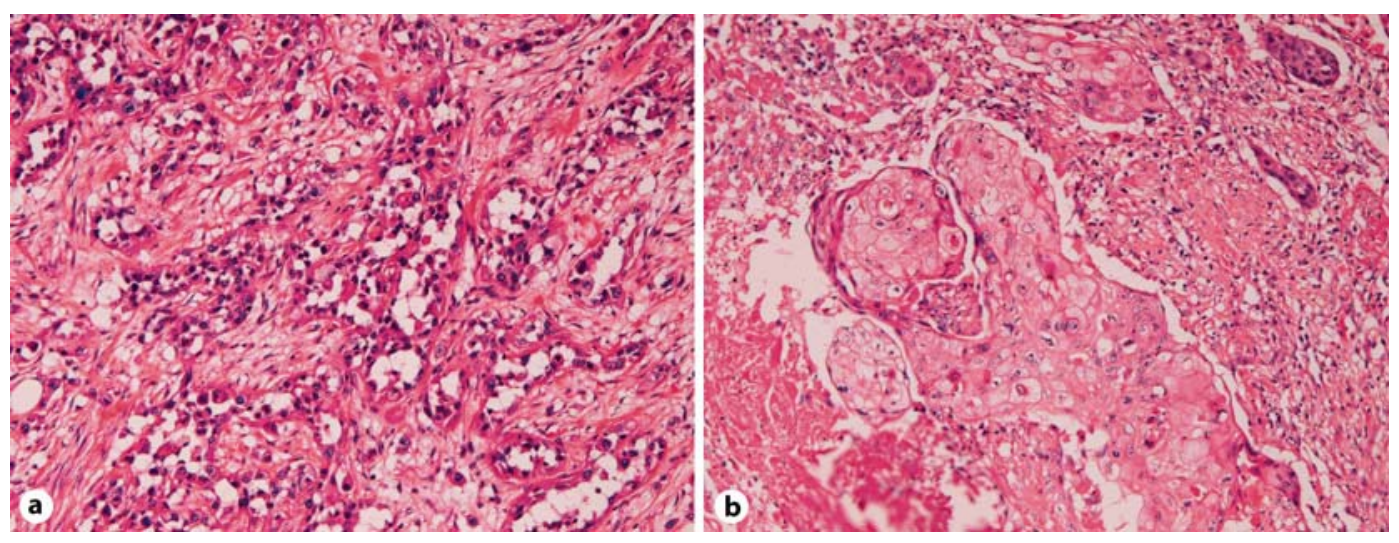

Fig. 1. Histology of case 1 (ASC). Tumor cells are composed of adenocarcinoma (moderately to poorly differentiated adenocarcinoma) element (a) and SCC element (b). a HE, $\times 200$. b HE, $\times 150$. 


\begin{tabular}{r|l|l|l}
$\begin{array}{r}\text { Case Reports in } \\
\text { Gastroanterology }\end{array}$ & $\begin{array}{l}\text { Case Rep Gastroenterol 2010;4:369-373 } \\
\text { DOl: 10.1159/000320675 }\end{array}$ & $\begin{array}{l}\text { Published online: } \\
\text { September 18, 2010 }\end{array}$ & $\begin{array}{l}\text { I 2010 S. Karger AG, Basel } \\
\text { ISSN 1662-0631 } \\
\text { www.karger.com/crg }\end{array}$ \\
\hline
\end{tabular}
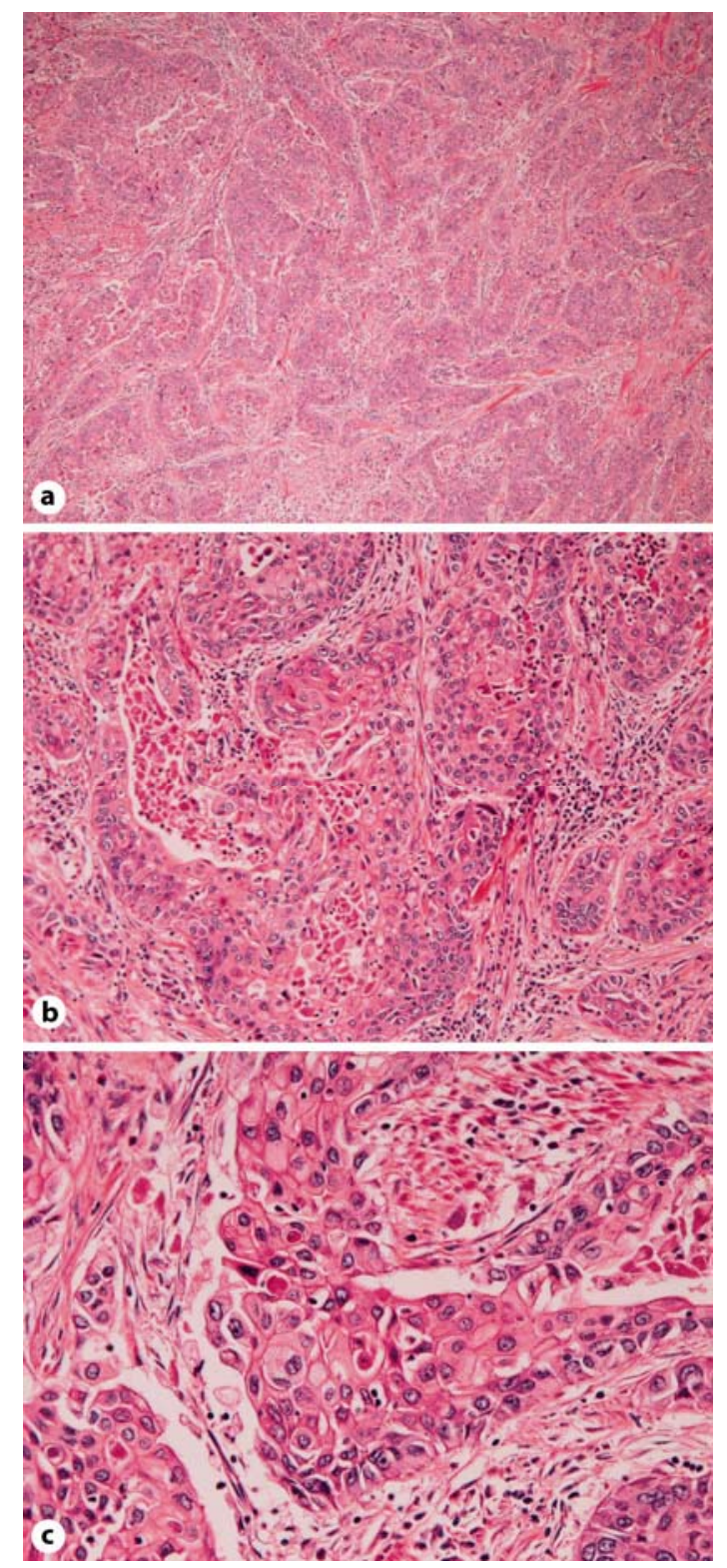

Fig. 2. Histology of case 2 (pure SCC). Tumor cells are composed of monotonous proliferation of SCC (a). The carcinoma cells show keratinization (b) and intercellular bridges (c). a HE, $\times 40$. b HE; $\times 150$. c HE, $\times 200$.

\section{References}

$\checkmark 1$ Okabayashi T, Hanazaki K: Surgical outcome of adenosquamous carcinoma of the pancreas. World J Gastroenterol 2008;14:6765-6770.

1 Htsu JT, Yeh CN, Chen YR, Chen HM, Hwang TL, Jan YY, Chen MF: Adenosquamous carcinoma of the pancreas. Digestion 2005;72:104-108.

3 Smoot RL, Zhang L, Sebo TJ, Que FG: Adenosquamous carcinoma of the pancreas: a single-institution experience comparing resection and palliative care. J Am Coll Surg 2008;207:368-370. 
4 Kardon DE, Thompson LD, Przygodzki RM, Heffess CS: Adenosquamous carcinoma of the pancreas: a clinicopathologic series of 25 cases. Mod Pathol 2001;14:443-451.

-5 Madura JA, Jarman BT, Doherty MG, Yum MN, Howard TJ: Adenosquamous carcinoma of the pancreas. Arch Surg 1999;134:599-603.

6 Anagnostopoulos GK, Aithal GP, Ragunath K, Kaye P, Rowlands BJ: Squamous cell carcinoma of the pancreas: report of a case and review of the literature. JOP 2006;7:47-50.

7 Brown HA, Dotto J, Robert M, Salem RR: Squamous cell carcinoma of the pancreas. J Clin Gastroenterol 2005;39:915-919.

8 Colarian J, Fowler D, Schor J, Poolos S: Squamous cell carcinoma of the pancreas with cystic degeneration. South Med J 2000;93:821-822.

-9 Brayko CM, Doll DC: Squamous cell carcinoma of the pancreas associated with hypercalcemia. Gastroenterology 1982;83:1297-1299.

10 Kloppel G, Hruban RH, Longnecker DS, Adler G, Kern SE, Partanen TJ: Ductal adenocarcinoma of the pancreas; in Hamilton SR, Aaltonen LA (eds): WHO Classification of Tumours. Pathology and Genetics, Tumours of the Digestive System. Lyon, IARC Press, 2000, pp 221-230. 